Proceedings

\title{
Contemporary research on spillover effects of COVID-19 in stock markets. A systematic and bibliometric review.
}

\author{
Hafiz Muhammad Arslan ${ }^{1}$, Bilal2, $^{2}$, Songsheng Chen ${ }^{3}$, Muhammad Farhan Bashir ${ }^{4}$ and Khoula Naseer \\ 1 Beijing Institute of Technology, Beijing, P.R. China; arslan@bit.edu.cn. \\ 2, * Hubei University of Economics, Wuhan, Hubei, P.R. China; bilal@hbue.edu.cn. \\ 3 Beijing Institute of Technology, Beijing, P.R. China; chenss@bit.edu.cn. \\ 4 Central South University, Changsha, Hunan, P.R. China; farhan.paks89@gmail.com. \\ 5 North China Electric Power university, Beijing, P.R. China; khoula728@gmail.com.
}

\begin{abstract}
Introduction

The spread of novel coronavirus (COVID-19) has significantly impacted the global financial markets over a relatively short period. The COVID pandemic's strong spillover effect on stock markets gained the attention of policymakers and academicians worldwide. The extant research has examined the influence of the COVID-19 pandemic on stock markets response in different contexts and yield mixed evidence. This research aims to synthesize the findings of the studies that have explored the impact of the COVID-19 pandemic on stock markets to identify the research progress and the research trends in this contemporary literature through a bibliometric and systematic review.
\end{abstract}

\section{Methods}

We have searched contemporary literature on spillover effects of COVID-19 on stock markets from Scopus databases. We have finalized 69 studies. We conducted the bibliometric analysis through bibliomatrix $\mathrm{R}$ package and systematic review by following PRISMA guidelines.

\section{Findings}

The most common keywords are COVID-19, coronavirus, pandemic, stock market, event study, stock market volatility, lockdowns, google trends. The finance research letter is the key journal in which 17 out of 69 papers have been published. Chinese researchers make the highest contributions with 17 publications out of 69 . We have identified five research trends: 1) fear of COVID-19 enhanced stock market volatility and reduced efficiency; 2) COVID-19 events analysis; 3) Investors sentiments analysis based on google trends during COVID-19; 4) sector-wise impact of COVID-19 in stock markets; 5) consequences of government response strategies on stock markets.

\section{Conclusion and implications}

Our study highlights the research progress on the spillover effects of COVID-19 on stock markets. Few studies have focused on negative news biasness in the stock market during the crisis period precisely. Thus, we suggest upcoming studies contribute to this issue empirically. We have observed a lack of research on the post-pandemic effects of COVID-19 on stock markets. Therefore, we suggest that upcoming studies explore the post-pandemic strategies' effects on stock markets. Our research also suggests that policymakers and researchers design preventive strategies for stock markets to avoid the detrimental effects of future infectious diseases and pandemics. Finally, we recommend that 
regulators must focus on small equity investors and small firms with high debt and working capital requirements in stimulus packages during the crisis period and provide awareness against panic selling and herding.

Keywords: COVID-19; Stock market; Bibliometric; Systematic review

\section{Introduction}

The spread of novel coronavirus (COVID-19) has significantly impacted the global financial markets over a relatively short span of time. The COVID-19 pandemic resulted in fragile stock markets and concluded that financial markets are greatly influenced by health crisis as no previous infectious diseases like H1N1, Ebola, polio virus and Zika virus has had such impact over stock markets [1].Specifically the stock markets around the world have responded to COVID-19 with strong negative returns and unprecedented volatility [2-5]. The COVID pandemic strong detrimental effect gained the attention of policy makers and academicians around the globe.

The aim of this research is to synthesize the findings of the studies that have explored the impact of COVID-19 pandemic on stock markets in order to identify the research progress and the research trends in this contemporary literature through bibliometric and systematic review. With this, there has been increased focus in analyzing the impact of COVID-19 on the stock market performance.

In order to investigate the literature on COVID-19 and stock market, we rely on bibliometric analysis to analyze 69 articles published during 2020, as published work on COVID-19 is of 2020 only. Current research attempt attempts to explore: (1) key research streams in the existing literature on COVID-19 and stock market. (2) Most influential aspects of current literature i.e., authors, countries, institutions, journals (3) future policy implications for policy makers. Through quantitative and qualitative literature review, we have identified five research clusters and have summarized key papers, research methodologies and data sources. Furthermore, key research areas, authors, institutions, countries and academic journals have also been identified.

Rest of the study as follows, section 2 presents the methods, section 3 provides the results of the study, and section 4 provides the discussion and concludes the study

\section{Methods}

We rely on bibliometric analytical approach to empirically analyze existing literature. Haddow [6] strongly advocated that bibliometric studies primarily rely on publication trend and citation analysis within the carefully selected scientific studies, where published research articles are the primary dataset. He further stated that bibliometric analysis identifies research domains' sub-fields, scientific terms and topics in a given field. Furthermore, citation, co-citation and author's networks are other analytical tools are also available during the data and research trend analysis.

To begin with, we used Web of Science to filter out recent publications [7]. For article selection, we used "COVID" and "stock market" in the search box: where Web of Science generated 128 research publications on November 28, 2020. To arrive at relevant sample size, we checked for duplicates; and kept the sample size as there were no duplicates in the selected studies. Next, we searched "COVID" in the title and abstract of the manuscripts. After second round, we kept the 160 research publications in 2020. In total 167 authors have contributed COVID-19 and Stock market publications in 39 research journals. These authors belong to 76 universities and research institutions from 17 countries.

Next, for bibliometric analysis we rely on VOSViewer software to investigate TITLE OF THE TOPIC; co-occurrence of key terms from title and abstract were analyzed, where each circle represents each terms and corresponding label. Furthermore, distance shown in graphical representations determines association between key terms, and number of 
occurrences determine the circle dimension [8]. Lastly, considering abstracts and titles avoids unnecessary recurrence of terms in rest of the research publications; we selected co-authorship, citation analysis, and co-citation to determine the research trends [8]. Based on empirical methodology by van Eck and Waltman [8], every cluster generated by the VOSViewer is represented by a different color in graphical representations. Finally, despite only selecting 69 number of papers from 128 research publications, research approach by current study will be a useful addition towards quantitative analysis of existing literature review

\section{Results}

\subsection{Influential Aspects of literature}

3.1.1. Key journals distribution and networks

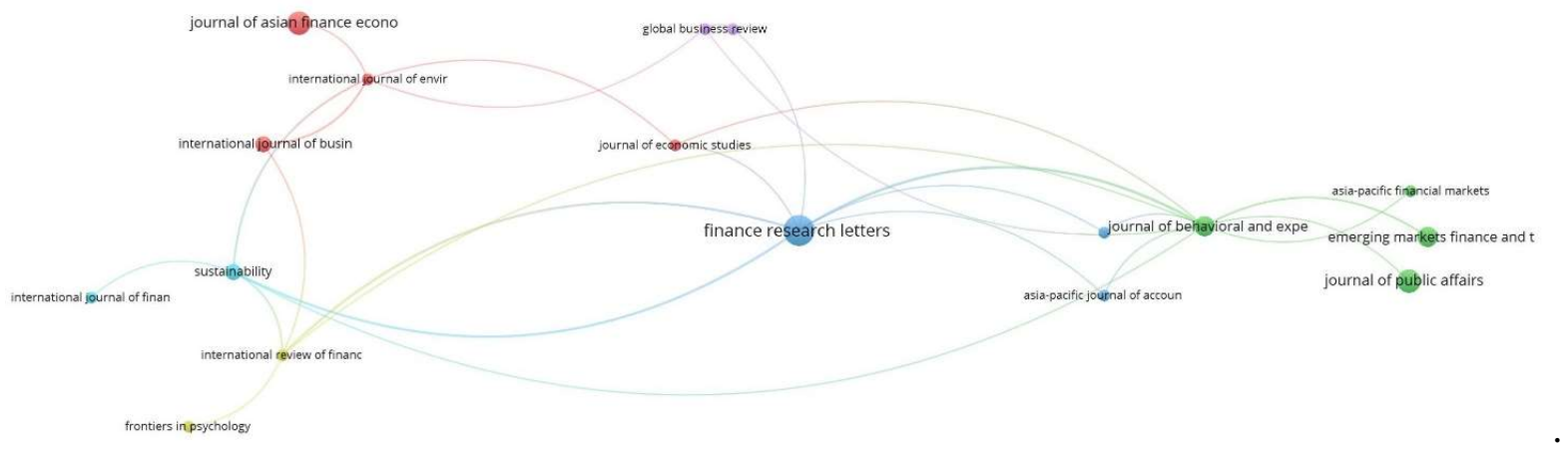

Figure 1. influential journals identified by VOS viewer software.

Journal distribution and networks are developed by BiblioShiny and VOSviewer to identify top journals on the topic based on following criterion. First criterion is the journal in which highest number of research papers published on the topic. Second criterion is the journals whose papers are mostly cited in the literature. As we can see from the fig 1 that most of the journals are purely from finance, economics, business and environment. It seems that this COVID and stock markets working during the pandemic is a phenomenon of behavioral science and psychology as well with finance and economics domain. Finance research letters is the most influential journal both in number of published papers on the topic and number of citations.

3.1.2. Influential authors, their countries of origin, institution affiliations, and networks 


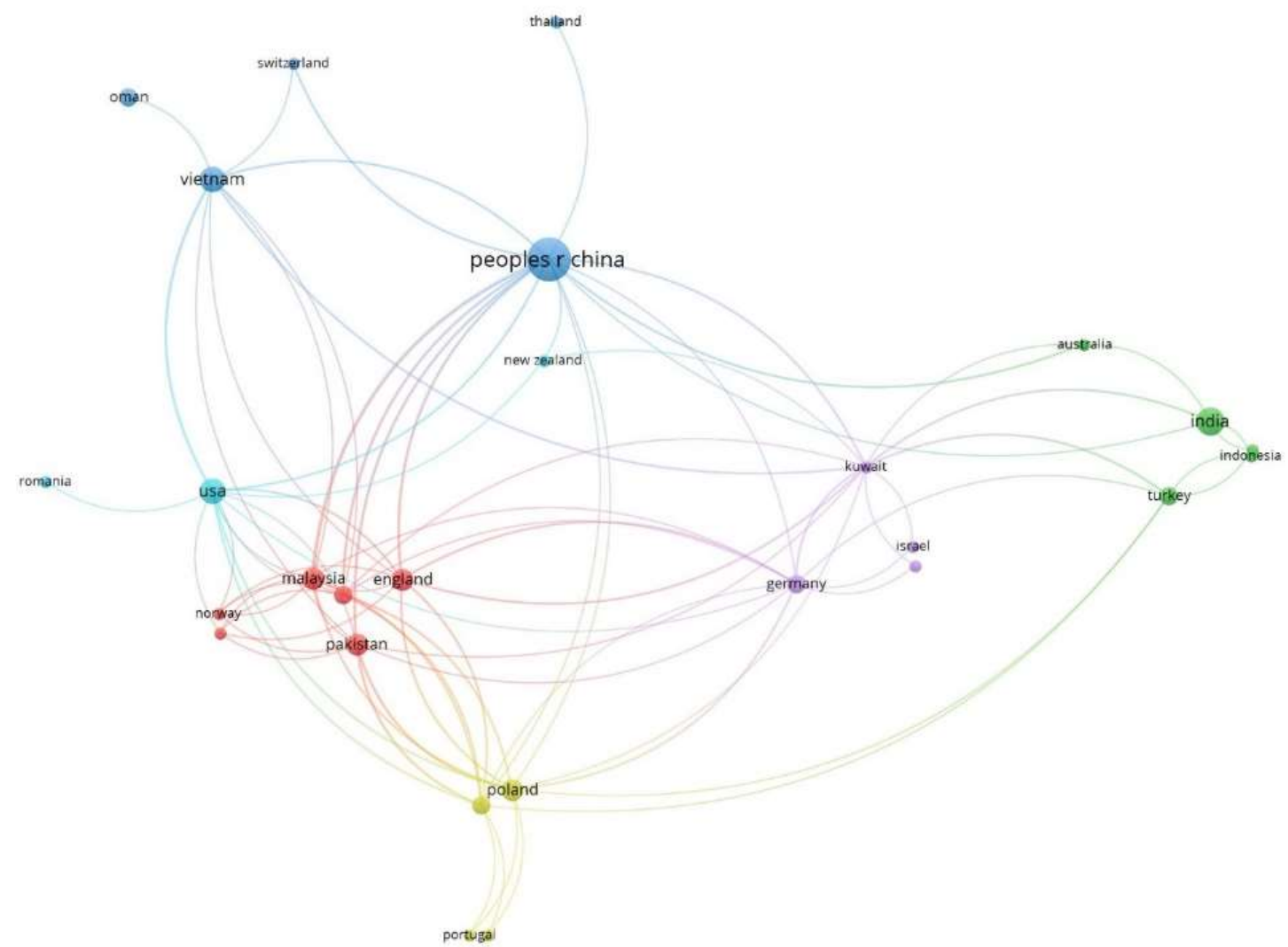

Figure 2. Citation network among author's countries of origin. The VOSviewer software is used create network.

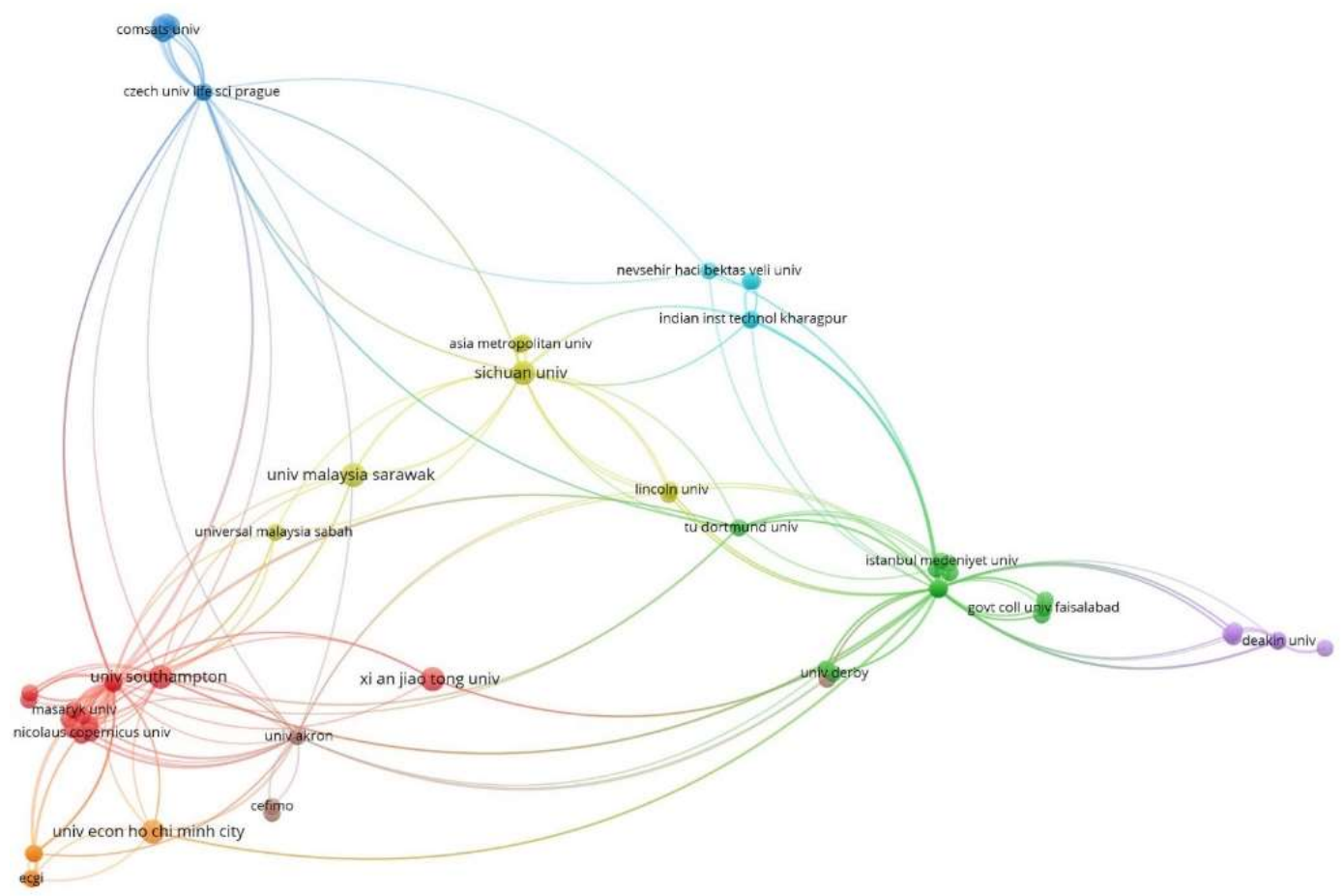


Figure 3. Citation network among author's institutional affiliations.

Authors are most integral part of this whole analysis. We used BiblioShiny and VOSviewer software to create networks among these authors on the basis of their country of origin and affiliation with their institutes and present these networks in fig 2 and Fig 3 . Chinese authors are the most influential authors then Asian authors come in the list with European at third spot and American authors at the fourth spot in the list of influential authors. Same is the case with the sequence of influential author's institutions affiliations.

\subsubsection{Keyword network: analysis for identifying research areas}

Keyword network from figure 4 explains that COVID-19, returns, stock market, event study, overreaction, crisis, SARS, volatility and risk are words repeated a lot in the literature.

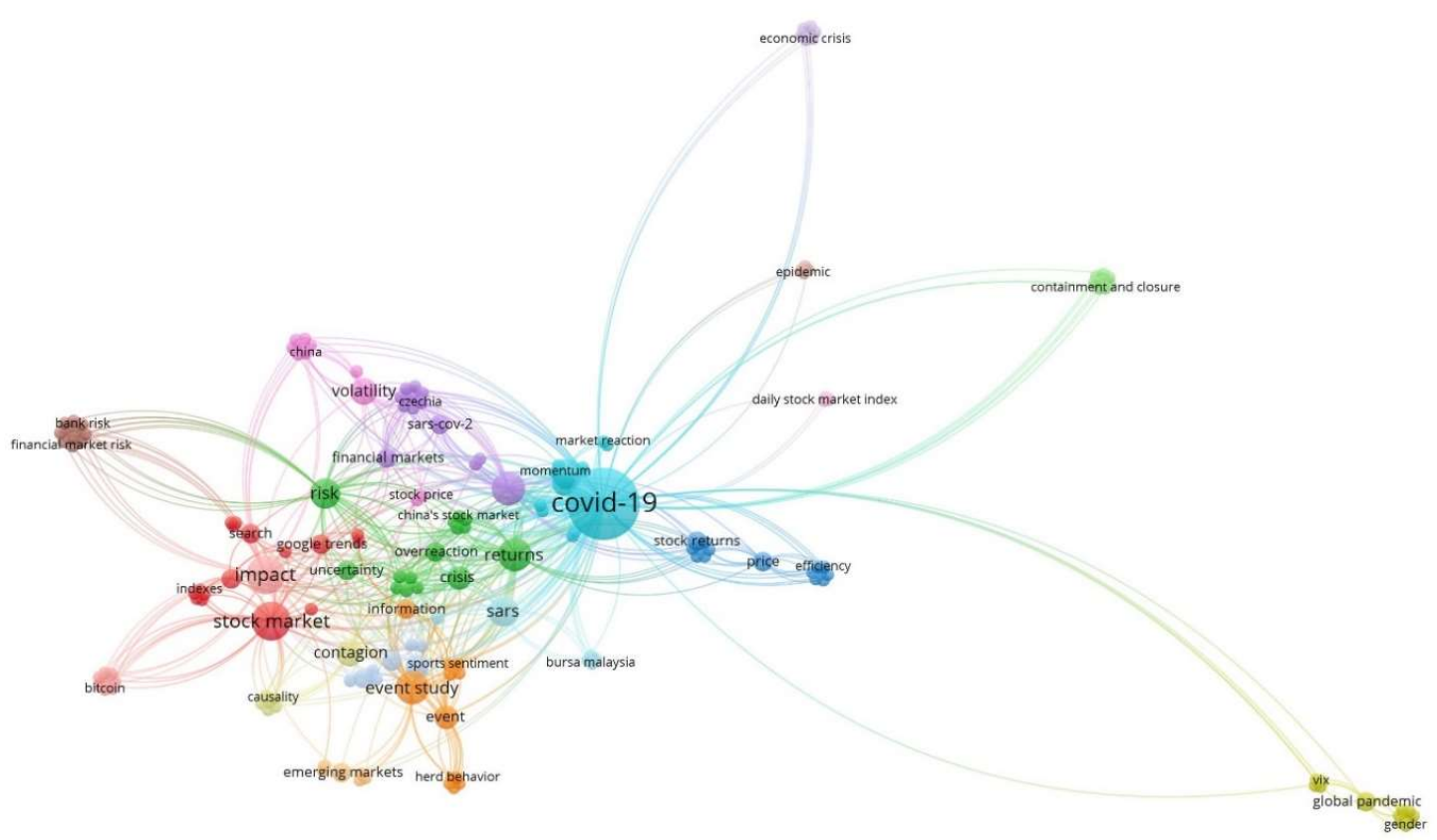

Figure 4. Keywords network analysis. The VOSviewer software is used create network.

\subsection{Systematic review}

The research trends in selected studies are identified through systematic review. Through close reading we have finalized the research trends based in similar research areas.

3.2.1. Fear of COVID-19 enhanced stock market volatility and reduced efficiency

Most prominent area in our selected studies (16/69 articles) is the influence of COVID-19 on stock market volatility. The nexus between stock market volatility and COVID-19 pandemic was explored using the following methods GARCH models (8 studies), Panel regression models (5 studies), Wavelet analysis (2 studies) and VECM (1 study). Thus, the most common method used is GARCH models. We have observed that these studies documented that COVID-19 pandemic enhanced stock market volatilities. The insights from highly cited studies are as follows. Sharif et al. [9], is the most cited study in this area (with 37 citations) that has examined the relationship between the spread of COVID-19 and stock market volatility considering the role of oil prices variations and economic uncertainty in the USA. Their findings indicate that COVID-19 has enhanced 
economic uncertainty, with more volatile stock markets and the oil price slump magnified the negative impact of COVID-19 on US economy [9].

Lahmiri et al. [10] document that several markets such as crypto currency, energy and precious metals are not integrated to equity markets in pre-pandemic phase due to totally different dynamics of these markets, however, during COVID-19 volatilities of crypto currency and energy market with equity markets reached at its peak. Baek et al. [11] investigated the COVID-19's impact on 30 US industries to find out that negative news regarding COVID-19 has more impact on stock market in the USA as compared to positive news i.e., increase in deaths has double negative impact on stock market as compared to recoveries (negativity biased).

As volatilities in stock markets surged universally during COVID-19, David et al.[12] investigated the response of stock markets towards recent pandemics and suggest that stock markets recovered quickly from recent pandemics but in case of COVID-19, the recovery of stock markets is expected to be slow due to higher market volatility.

Zaremba et al. [13] is the second highly cited study (with 18 citations) which investigated the impact of policy response to COVID-19 pandemic and stock market volatility in 67 countries and documented that COVID-19 related restrictions enhanced volatilities in the financial markets, which further induced panic in all financial markets leading to stock markets crashes. Chiah et al. [14] argued about the perception of equity investors regarding stock markets during COVID-19 as casinos. Because of huge volatilities, risk levels surpassed aversion sentiment and trading in the specific situation become an alternative to gambling.

A section of recent academic research on emerging markets discussed impact of COVID-19 on stock markets liquidity indicates that the relationship between low numbers of coronavirus cases with high government intervention in emerging markets (those are not geographically connected with Asian emerging markets) resulted in high liquidity in emerging stock markets [15]. These results are consistent with previous studies like [16,17] and states that equity investors move to safer assets like gold and other metals during uncertain times resulted in reduced liquidity in stock markets while reduced number of coronavirus cases and deaths shows reduced uncertainty resulted in improved liquidity in the market. Same is the case with the Vietnam market where number of confirmed cases adversely affected stock returns and their volatilities [18]. Coronavirus spread adversely impacted stock markets in emerging markets and as the number of coronavirus cases increase in any emerging economy it resulted in stock market crash of that economy with huge volatility in the stock market of that economy [19]. Author suggest that stock returns will recover with the availability of vaccine and herd immunity.

\section{Efficiency and herding in stock markets during COVID-19}

In this portion of first cluster a part of literature focuses efficient market hypothesis and herding in stock markets which are spillover effect of volatility. Reflection of new available information into stocks prices of any stock market is the efficiency of that stock market and efficiency of financial markets are very important in long run and specifically during any crisis because market efficiency will let society for proper resource allocation and capital formation which is a key to economic development and crisis management [20]. WHO declared Public Health Emergency of International Concern (PHEIC) regarding COVID-19 on January 30, 2020 and a pandemic on 11 March. US stock markets response was too slow during PHEIC and pandemic announcement whereas it was totally rational that the virus having contagion nature, can affect US market as well because of no of large metropolitan cities and millions of travelers from all over the globe [21]. COVID-19 information was a public information and according to Fama [22] if stock market is efficient then all public information must reflect in prices of stocks which S\&P 500, NYSE and NASDAQ did not reflect timely.

Chang [23] employ herding concept to verify efficiency of stock markets during COVID-19. Efficiency of stock market is based on investor's investment on the basis of fundamentals but when investors are following other investor's investment decisions then 
fundamentals take back seat and Christie and Huang, [24] identified this psychological phenomenon as herding in stock market. Global financial crisis of 2007-2009 has made investors more vulnerable during any global crisis and in that situation investors show strong herding behaviour [23] which totally disturbed identification of mispriced securities by analysts who were following asset pricing theories and fundamental analysis. COVID-19 which was declared a pandemic by WHO has created panic in alternative energy investors from USA, Europe and Asia and they have shown strong herding during COVID-19 when oil prices were also at extreme low level.

At this point some propositions can be summarized from the cluster 1:

- COVID related restrictions created panic at national level in most of the countries influenced equity investors to quit quickly and move their finances to safe heaven like Gold resulted in huge volatilities in financial markets globally.

- Stock markets sensitivity is biased towards negative news, like growth in no of new cases as compared to positive news like growth in recoveries.

- Huge volatilities resulted in gigantic risk which attracted gamblers in equity markets because of appropriate appetite in developed nations.

- Emerging stock markets faced liquidity crunch during this crisis which vanished with government interventions and monitory policy relaxations.

- Investors vulnerability during COVID-19 resulted in herding behaviour verified in US and European stock markets concluded that stock markets in developed countries are also not efficient all the times.

\subsubsection{COVID-19 events analysis}

The second cluster is composed of 16 articles encompassing several issues pertaining to abnormal returns either negative or positive resulted in COVID-19. Papers combined in this cluster has taken COVID-19 and spillover steps like lock downs, travel bans, closure of public places as events and analyzed the response of stock markets with respect to different events. Events have integral role in stock market indexes movement in both directions all over the world.

The most cited paper (with 43 citations in such a short span of time) is by Ahundjanov et al. [25] which focuses on whether COVID-19 has any impact in Chinese stock markets and concluded that significant negative abnormal return were figured during the period of analysis and these abnormal returns are negatively related to growth in total confirmed cases and no of deaths caused by COVID-19. Liu et al. [26] analyze the role of COVID-19 in regional context and identified that COVID-19 has same significant negative impact on major stock markets but it was interesting to note that Asian stock markets respond quickly to this pandemic with more lethal impact and also recovered earlier. Schell et al. [27] has analyzed COVID-19 impact on stock markets in context of Public Health Emergency of International Concern (PHEIC) announcements by WHO and the consequent impact on stock markets in history from 2005 onward. WHO has declared Public Health Emergency of International Concern (PHEIC) six times: H1N1 in 2009, Ebola and polio virus in 2014, Zika virus in 2016, again Ebola in 2019 and then COVID-19 in 2020 after 2005 to get internationally coordinated response from member countries. Only Ebola (PHEIC) announcement in 2014 has impact like COVID-19 at announcement date and in the adjacent event windows because 11 indices exhibits significant negative abnormal returns at announcement date whereas other (PHEIC) announcements like H1N1 in 2009, polio virus in 2014, Zika virus in 2016, Ebola in 2019 were totally ignored by analysts and investors.

Few articles discuss the psychological impact of lockdowns and the resulted panic of investors on stock markets. The author also confirm that Conventional indexes performed better than sharia compliant indexes during COVID and no of deaths were less significant as compared to new daily no of cases in Malaysia. It was interesting to note that before movement control order all stock market indexes in Malysian economy abnormal returns 
were significant and negative but these indexes turn to positive after movement control order as it seems that investors perceive $\mathrm{MCO}$ as governments commitment to contain Corona with stimulus package send positive signal to financial and corporate sector resulted in all index recoveries [28].

In this cluster a part of literature focuses on the Asian context with price movement of stocks on the basis of information diffusion hypothesis (IDH) and price pressure hypothesis $(\mathrm{PPH})$. News with fundamental information results in permanent price change with no reversal according to IDH whereas PPH states that with new information temporary price movement occurs which ultimately revert back to security's fundamental value. Shen [29] concluded that price pressure hypothesis prevails in case of GO stock because of significant negative abnormal return at the event date (11 March 2020) with reversal pattern whereas there was no negative abnormal return found at event date in case of SAH stocks, while cumulative abnormal return continue to increase in adjacent days in Chinese's stock markets .

Visegard countries (Czechia, Hungary, Poland, and Slovakia) experienced currency depreciation with the growth of no of coronavirus cases first then stock exchange indexes downfall and increase in volatility of stock exchanges during COVID-19 [30]. Extensive media coverage to COVID-19 and movement control orders create panic at individual level resulted in the form of overreaction in short run followed price pressure hypothesis with recovery of stock markets ultimately [31].

Some propositions from cluster 2 can be drawn:

- COVID-19 initially ignored by stock markets and then markets overreacted after lock downs announced. Asian stock markets respond and recover quickly as compared to developed stock markets.

- COVID-19 and Ebola (PHEIC) announcement in 2019 and 2014 negatively affected stock markets, while other PHEICs have no effect on financial markets.

- $\quad$ Price pressure hypothesis prevails in case of GO stocks because of significant negative abnormal returns at event date (11 March) and revert back in coming weeks.

- COVID-19 resulted in currency depreciation and huge volatilities in stock markets globally but financial heat is felt in Asia first and then in developed economies.

\subsubsection{Investor's sentiments analysis based on google trends during COVID-19}

This cluster includes 10 articles that emphasize the role of COVID-19 on sentiments, measured through frequency of search terms on different search engines and quantification of the impact of these sentiments on stock index movement. Traditional researches has measured effects of unanticipated incidents on stock markets through intervention analysis [32] and event study [33]. Liu et al. [26] has measured market sentiments towards unexpected incidents through Google and Baidu search index and quantify the impact of these sentiments on stock prices of the affected industry. Search data on the internet is timely reflection of public perception which significantly project investor decision making.

The most cited study is Lyócsa et al. [34], which is motivated to gauge the fear of 'corona crash' on 10 largest stock markets consisting $80 \%$ market capitalization globally. Coronavirus fear has created panic at global level and the fear of Corona virus manifested in excess search volume at search engines and Google searches for coronavirus are not simply correlated: these searches predict variance in the future for every country mentioned above.

From 19 Feb 2020 to March 23, 2020 S\&P 500 index lost 35\% of its market capitalization. Magnitude of this loss in American history is comparable to 2008 American financial crisis, Black Monday 1987, and Great depression in 1929. McFall [35] identified such evaporation of wealth not only in America but in all countries were evident with dire financial and psychological consequences. Financial contagion were more rapid in stock markets of whole world when compared to pandemic nature of this virus as stock markets crashed 
globally with in very short span of time [36]. Whereas Baumöhl et al. [37] acknowledged systematic risk in banking sector and spillover impact in other industries is denser in Corona pandemic as compared to 2008 financial crisis.

Few articles discussed technology adaptability as buffer for COVID-19 negative implication like Ding et al. [38] recognized that, firms with high digital transformation have shown resilience towards negative market sentiments in their stock prices whereas low digitalized firms are most affected from negative market sentiments [25]. Electronic, print and social media content is also another platform which educate people on issues and news on these platforms also affect risk perception of population at macro and investors at micro level [39]. Engelhardt et al. [40] claimed that rationality of investors has little contribution in tis overreaction as compared to higher news attention. US stock markets crash resulted in 3.5 trillion dollars loss whereas G8 countries also lost 200 billion dollars in stock market crashes due to COVID-19 news hype [40].

In this cluster a part of literature focuses on the relationship of reliability of coronavirus data and its impact on investor's sentiments. Fang and Peress [41] argued that fake news is not affecting stock market during bullish and bearish situations whereas wider media coverage of negative news has negative effect on stock market returns, specifically during bullish markets scenarios [42]. Erdem [43] stated that societies with high personal, civil and economic freedom have strong institutions with reliable statistics and are considered more-freer countries. Lee [44] identified daily news sentiment index and google trends as effective proxies for COVID-19 pandemic sentiments with varying level of correlations in different industries. Utility sector, financial, information technology and health care sectors are identified as uncorrelated sectors with the corona sentiments whereas communication, industrial, energy and material sectors have strong correlations with the sentiments and are most affected sectors during COVID-19. Lyocsa [45] claimed that coronavirus fear resulted in huge volatility which ultimately translated into strong negative shocks and large crashes in stock markets all over the world.

At this point some propositions can be summarized from the cluster 3:

- Excess search volume of COVID-19, at Google search is timely reflection of public perception of Corona fear which can project investor decision making.

- High digital transformation of firms proved to be the buffer against negative financial implications of COVID-19.

- More-freer countries have less impact of COVID-19 cases on stock market volatilities as compared to less-freer countries with same number of COVID cases and deaths.

\subsubsection{Sector-wise impact of COVID-19 in stock markets}

Fourth cluster is composed of 14 articles dealing with several sectors in economies linked in a more or less direct way to firm level impact of COVID-19 on stock markets. Papers selected in this cluster on the basis of commonality of COVID-19 impact at sectorial level in different stock markets.

The most cited study is He [46], which has applied event study, January 23 as event day and selected 160 trading days before the event date as the forecast period with every five trading days around the event occurrence date as the event window period. The author conclude that transportation and tourism, mining and electricity are adversely affected industries whereas high-tech manufacturing, software development, online education and health care are positively affected industries during pandemic.

Tourism industry is the most affected sector in all economies after corona pandemic and it all started after implementation of lockdowns at mass level across the globe. Prices of tourism industry stocks has become inelastic to world daily new corona cases as it seems that before commercial availability of coronavirus vaccine nothing may be normal again globally [47]. Air travel is an important segment of whole tourism supply chain (TSC) and this sector is worst performer in Australia, Canada, UK and US after declaration 
by WHO on global pandemic outbreak at 11 March [48]. Petroleum, real estate, entertainment, and hospitality sectors from S\&P 1500 has shown abnormal negative returns after COVID-19 as lockdowns in US and all over the world results in low consumption of oil with huge oil inventories, and low activity in entertainment and hospitality industries. Transport, hospitality, food and beverage are most affected areas at macro level in major economies with bear stock markets accompanied by huge volatilities in uncertain environment [50].

Singh [50] and Joshi [51] argued that Asian stock markets crashed due to Corona pandemic and significant negative abnormal returns were identified in Shanghai, Shenzhen and Nikkei and MSCI all country index. Mazur [52] agrees with He et all. [53] and argued that pharmaceutical manufacturing is focused by investors as pharmaceutical sector has strong role in disease alleviation with IT and software companies whereas developed markets r/epresentative indexes like S\&P 1500 index also identified natural gas, food, healthcare, and software stocks with positive abnormal returns during pandemic and a new scenario of "work at home", online gaming and online shopping created opportunities for different software companies and health care stocks.

Few articles identified the most affected sectors of stock markets due to COVID-19. Liu et al. [54] and He et al. [53] argued that transportation, tourism, mining, and catering companies are biggest losers during pandemic in short and long run. Whereas financial sector is the most affected sector in Veitnam while overall stock market crashed with increase in number of coronavirus cases [18]. Chaudhary et al.[55] stated that Auto, Bankex, Consumer Durables, Capital Goods, Fast Moving Consumer Goods, Information Technology, and Realty have shown negative abnormal returns except health care sector during post-crisis period when compared to pre-crisis period [56].

Shehzad et al. [57] analyzed that COVID-19 has tested the health care system of developed world and health care is choked in most developed nations. Governments has to announce lockdowns when not able to manage disease at their territories resulted in stock market crashes even in US, Itlay, Spain France and UK. Major stock markets has officially labelled as bear markets because of severe impact on listed firms in all sectors of economies.

In this cluster, a part of literature focuses behavioral finance theories and validate psychological and behavioral disturbance by natural disasters at mass level. Investor's vulnerable sentiments reflects in securities earnings and price volatilities even COVID-19 has disturbed sentiments of investors in developed and rich nations. Lima et al. [58] argues that COVID-19 has varying effect on different industries with different degree of responsiveness. Stocks with lower institutional ownership have strongly overreacted movement control orders from respective governments [59]. Hoshi \& Kashyap [60] connoted the change in rule of game regarding stock market during national or global crisis. Herding dominates whereas fundamentals and commonsense normally erode from the stock market which results in panic from investors behaviour and psychology during investment decisions but the logic of macroeconomic indicator's superiority over company fundamentals still persists in crisis time periods.

Some propositions emerged from the analysis of cluster 4 :

- Tourism, transportation, petroleum, catering, auto, financial, consumer durables, electricity and mining are the most affected sectors respectively.

- Health care, pharmaceutical, online shopping, IT and online education sectors are not affected by COVID-19, infect performed better during COVID-19.

- Health disaster with contagion nature disturbed individual investors psychologically with vulnerable behavior resulted in panic selling and stock market crashes.

\subsubsection{Consequences of government response strategies on stock markets}

The cluster includes 9 articles that emphasize the role of stimulus package during corona crash of stock markets. Stimulus packages were the backup plans governments 
announced at different stages of this pandemic. COVID-19 is the most surprised event till date in $21^{\text {st }}$ century resulted in emergency actions by governments after first information came into knowledge of the world that it is a contagion disease and social distancing may be the very first proper response for this disease before any medicinal treatment and vaccination process. Social distancing is very costly in this globalized world and resulted in disturbance of supply chains, inflation, unemployment, sales reductions, lower earnings per share and ultimately lower or negative returns from companies. It all affected cash flows of companies without considering the size of firms resulted in majority red signs in stock markets which induces governments to jump in and announce some support in monitory terms. Governments have to announce stimulus packages for some backup so that business may survive and recover after lockdowns and social distancing.

The most cited paper (with 44 citations in such a short span of time) is by Goodell [61] which focuses policy steps taken by governments in response of this disease while stimulus package played integral role to support stock markets crashes. The author states that a contagion disease like COVID-19 can crash most of the stock markets all over the world, enhance budget deficits for governments irrespective of developed or developing economies, can disrupt supply chains globally without destroying physical infrastructure unlike in wars, earthquakes and floods and create huge uncertainty regarding future events globally. Governments have to jump in and must support through stimulus packages so, that investors may survive in the stock market. Whereas interestingly Phan [62] and Narayan [63] explained COVID-19 a case of learning from experience of other countries, the late it comes to any country the more information that country has for policy response and its implementation.

Few articles discuss that, social distancing, containment and health response with income support packages are the actions which different governments, whereas more awareness, testing and quarantine facilities and specifically the stimulus packages resulted in positive stock market returns [64]. Small firm's returns did not respond positively to stimulus package announced by Fed in US as compared to large firms [65]. Pakistan stock market initially dipped due to COVID-19 but after announcement of relief package by Government of Pakistan for industries and huge cut in interest rate by State Bank of Pakistan resulted in positive returns from Pakistan Stock Exchange [66]. Wagner [67] discussed the soft targets of COVID-19 in stock markets as Companies with high debts racked in their liability side of balance sheets and low cash in assets. These companies are the easiest prey of this health cum financial disaster irrespective of stimulus packages announced by governments all over the world.

- Some propositions from cluster 2 can be drawn:

- $\quad$ Stock markets take stimulus packages positively all over the world

- Small firms with high debts and low working capital have low financial shock absorption capacity and caught as prey of COVID-19

\section{Discussion and conclusions}

This study contributes to the academic literature by summarizing the contemporary research on impact of COVID-19 pandemic on stock markets. Our study provides the insights about the selected 69 studies from the influential aspects using bibliometric analysis which are as follows: the most common keywords are COVID-19, event study, coronavirus and stock markets. The most contributing journal and authors are Finance research letters and Aslam F, Ferreira P, and Narayan Pk respectively. We have identified five research trends: 1) fear of COVID-19 enhanced stock market volatility and reduced efficiency; 2) COVID-19 events analysis; 3) Investors sentiments analysis based on google trends during COVID-19; 4) sector-wise impact of COVID-19 in stock markets; 5) consequences of government response strategies on stock markets.

Our study highlights the research progress on the spillover effects of COVID-19 on stock markets. Few studies have focused on negative news biasness in the stock market 
during the crisis period precisely. Thus, we suggest upcoming studies contribute to this issue empirically. We have observed a lack of research on the post-pandemic effects of COVID-19 on stock markets. Therefore, we suggest that upcoming studies explore the post-pandemic strategies' effects on stock markets. Our research also suggests that policymakers and researchers design preventive strategies for stock markets to avoid the detrimental effects of future infectious diseases and pandemics. Finally, we recommend that regulators must focus on small equity investors and small firms with high debt and working capital requirements in stimulus packages during the crisis period and provide awareness against panic selling and herding.

\section{References}

1. Corbet, S., Larkin, C., and Lucey, B. (2020). The contagion effects of the covid-19 pandemic: Evidence from gold and cryptocurrencies. Finance Research Letters, 101554.

2. Al-Awadhi, A. M., Alsaifi, K., Al-Awadhi, A., and Alhammadi, S. (2020a). Death and contagious infectious diseases: Impact of the COVID-19 virus on stock market returns. Journal of Behavioral and Experimental Finance, 27. https://doi.org/10.1016/j.jbef.2020.100326.

3. Baker, S. R., Bloom, N., Davis, S. J., Kost, K. J., Sammon, M. C., and Viratyosin, T. (2020). The unprecedented stock market impact of COVID-19. National Bureau of Economic Research.

4. Ramelli, S., and Wagner, A. F. (2020). Feverish stock price reactions to covid-19.

5. Zhang, D., Hu, M., and Ji, Q. (2020). Financial markets under the global pandemic of COVID-19. Finance Research Letters, 101528.

6. Haddow, G. (2013). Bibliometric research. In Research methods: Information, systems and contexts (pp. 219-244). Tilde University Press.

7. 7. Mongeon, P., \& Paul-Hus, A. (2016). The journal coverage of Web of Science and Scopus: a comparative analysis. Scientometrics, 106(1), 213-228.

8. 8. Van Eck, N. J., \& Waltman, L. (2013). VOSviewer manual. Leiden: Univeristeit Leiden, 1(1), 1-53.

9. 9. Sharif, A., Aloui, C., and Yarovaya, L. (2020). COVID-19 pandemic, oil prices, stock market, geopolitical risk and policy uncertainty nexus in the US economy: Fresh evidence from the wavelet-based approach. International Review of Financial Analysis, 70. https://doi.org/10.1016/j.irfa.2020.101496

10. 10. (Lahmiri \& Bekiros, 2020) Lahmiri, S., \& Bekiros, S. (2020). Randomness, informational entropy, and volatility interdependencies among the major world markets: The role of the COVID-19 pandemic. Entropy, 22(8). https://doi.org/10.3390/E22080833

11. 11. (Baek, Mohanty, \& Glambosky, 2020)Baek, S., Mohanty, S. K., \& Glambosky, M. (2020). COVID-19 and stock market volatility: An industry level analysis. Finance Research Letters, 37. https://doi.org/10.1016/j.frl.2020.101748

12. 12. (David, Inácio, \& Tenreiro Machado, 2021) David, S. A., Inácio, C. M. C., \& Tenreiro Machado, J. A. (2021). The recovery of global stock markets indices after impacts due to pandemics. Research in International Business and Finance, 55. https://doi.org/10.1016/j.ribaf.2020.101335

13. 13. Zaremba, A., Kizys, R., Aharon, D. Y., \& Demir, E. (2020). Infected Markets: Novel Coronavirus, Government Interventions, and Stock Return Volatility around the Globe. Finance Research Letters, 35. https://doi.org/10.1016/j.frl.2020.101597

14. 14. Chiah, M., \& Zhong, A. (2020). Trading from home: The impact of COVID-19 on trading volume around the world. Finance Research Letters, 37. https://doi.org/10.1016/j.frl.2020.101784

15. 15 Haroon, O., \& Rizvi, S. A. R. (2020). Flatten the Curve and Stock Market Liquidity-An Inquiry into Emerging Economies. Emerging Markets Finance and Trade, 56(10), 2151-2161. https://doi.org/10.1080/1540496X.2020.1784716

16. Baur, D. G., \& Lucey, B. M. (2010). Is gold a hedge or a safe haven? An analysis of stocks, bonds and gold. Financial Review, 45(2), 217-229.

17. Connolly, R., Stivers, C., \& Sun, L. (2005). Stock market uncertainty and the stock-bond return relation. Journal of Financial and Quantitative Analysis, 161-194.

18. Anh, D. L. T., \& Gan, C. (2020). The impact of the COVID-19 lockdown on stock market performance: evidence from Vietnam. Journal of Economic Studies. https://doi.org/10.1108/JES-06-2020-0312

19. Cao, K. H., Li, Q., Liu, Y., \& Woo, C.-K. (2020). Covid-19's adverse effects on a stock market index. Applied Economics Letters. https://doi.org/10.1080/13504851.2020.1803481

20. Rizvi, S. A. R., \& Arshad, S. (2016). How does crisis affect efficiency? An empirical study of East Asian markets. Borsa Istanbul Review, 16(1), 1-8.

21. Evangelos, V. (2020). Efficient markets hypothesis in the time of COVID-19. Review of Economic Analysis, 12(2), 1-28. 
22. Malkiel, B. G., \& Fama, E. F. (1970). Efficient capital markets: A review of theory and empirical work. The Journal of Finance, 25(2), 383-417.

23. Chang, C.-L., McAleer, M., \& Wang, Y.-A. (2020). Herding behaviour in energy stock markets during the Global Financial Crisis, SARS, and ongoing COVID-19*. Renewable and Sustainable Energy Reviews, 134. https://doi.org/10.1016/j.rser.2020.110349

24. Christie, W. G., \& Huang, R. D. (1995). Following the pied piper: Do individual returns herd around the market? Financial Analysts Journal, 51(4), 31-37.

25. Ahundjanov, B. B., Akhundjanov, S. B., \& Okhunjanov, B. B. (2020). Information search and financial markets under COVID19. Entropy, 22(7). https://doi.org/10.3390/e22070791

26. Liu, H., Manzoor, A., Wang, C., Zhang, L., \& Manzoor, Z. (2020). The COVID-19 outbreak and affected countries stock markets response. International Journal of Environmental Research and Public Health, 17(8). https://doi.org/10.3390/ijerph17082800

27. Schell, D., Wang, M., \& Huynh, T. L. D. (2020). This time is indeed different: A study on global market reactions to public health crisis. Journal of Behavioral and Experimental Finance, 27, 100349. https://doi.org/https://doi.org/10.1016/j.jbef.2020.100349.

28. Chia, R. C.-J., Liew, V. K.-S., \& Rowland, R. (2020). Daily new COVID-19 cases, the movement control order, and Malaysian stock market. International Journal of Business and Society, 21(2), 553-568.

29. Shen, D., \& Zhang, W. (2020). Stay-at-Home Stocks Versus Go-Outside Stocks: The Impacts of COVID-19 on the Chinese Stock Market. Asia-Pacific Financial Markets. https://doi.org/10.1007/s10690-020-09322-4.

30. Czech, K., Wielechowski, M., Kotyza, P., Benešová, I., \& Laputková, A. (2020). Shaking stability: COVID-19 impact on the Visegrad Group countries' financial markets. Sustainability (Switzerland), 12(15). https://doi.org/10.3390/SU12156282.

31. He, Q., Liu, J., Wang, S., \& Yu, J. (2020). The impact of COVID-19 on stock markets. Economic and Political Studies, 1-14. https://doi.org/10.1080/20954816.2020.1757570.

32. 32 Box, G. E. P., \& Tiao, G. C. (1975). Intervention analysis with applications to economic and environmental problems. Journal of the American Statistical Association, 70(349), 70-79.

33. MacKinlay, A. C. (1997). Event studies in economics and finance. Journal of Economic Literature, 35(1), 13-39.

34. Lyócsa, Š., \& Molnár, P. (2020). Stock market oscillations during the corona crash: The role of fear and uncertainty. Finance Research Letters, 36. https://doi.org/10.1016/j.frl.2020.101707

35. Helppie McFall, B. (2011). Crash and wait? The impact of the Great Recession on the retirement plans of older Americans. American Economic Review, 101(3), 40-44.

36. Akhtaruzzaman, M., Sensoy, A., \& Corbet, S. (2020). The influence of bitcoin on portfolio diversification and design. Finance Research Letters, 37, 101344.

37. Baumöhl, E., Bouri, E., Hoang, T.-H.-V., Shahzad, S. J. H., \& Výrost, T. (2020). From physical to financial contagion: the COVID-19 pandemic and increasing systemic risk among banks.

38. Ding, D., Guan, C., Chan, C. M. L., \& Liu, W. (2020). Building stock market resilience through digital transformation: using Google trends to analyze the impact of COVID-19 pandemic. Frontiers of Business Research in China, 14(1). https://doi.org/10.1186/s11782-020-00089-z

39. Khan, K., Zhao, H., Zhang, H., Yang, H., Shah, M. H., \& Jahanger, A. (2020). The impact of COVID-19 pandemic on stock markets: An empirical analysis of world major stock indices. Journal of Asian Finance, Economics and Business, 7(7), 463-474. https://doi.org/10.13106/jafeb.2020.vol7.no7.463

40. Engelhardt, N., Krause, M., Neukirchen, D., \& Posch, P. (2020). What drives stocks during the corona-crash? News attention vs. rational expectation. Sustainability (Switzerland), 12(12). https://doi.org/10.3390/su12125014

41. Fang, L., \& Peress, J. (2009). Media coverage and the cross-section of stock returns. The Journal of Finance, 64(5), $2023-2052$.

42. Cepoi, C.-O. (2020). Asymmetric dependence between stock market returns and news during COVID-19 financial turmoil. Finance Research Letters, 36. https://doi.org/10.1016/j.frl.2020.101658

43. Erdem, O. (2020). Freedom and stock market performance during Covid-19 outbreak. Finance Research Letters, 36. https://doi.org/10.1016/j.frl.2020.101671

44. Lee, H. S. (2020). Exploring the initial impact of COVID-19 sentiment on US stock market using big data. Sustainability (Switzerland), 12(16). https://doi.org/10.3390/su12166648

45. Lyócsa, Š., Baumöhl, E., Výrost, T., \& Molnár, P. (2020). Fear of the coronavirus and the stock markets. Finance Research Letters, 36. https://doi.org/10.1016/j.frl.2020.101735

46. He, P., Sun, Y., Zhang, Y., \& Li, T. (2020). COVID-19's Impact on Stock Prices Across Different Sectors-An Event Study Based on the Chinese Stock Market. Emerging Markets Finance and Trade, 56(10), $2198-2212$. https://doi.org/10.1080/1540496X.2020.1785865

47. Liew, V. K.-S. (2020). The effect of novel coronavirus pandemic on tourism share prices. Journal of Tourism Futures. https://doi.org/10.1108/JTF-03-2020-0045 
48. Maneenop, S., \& Kotcharin, S. (2020). The impacts of COVID-19 on the global airline industry: An event study approach. Journal of Air Transport Management, 89. https://doi.org/10.1016/j.jairtraman.2020.101920

49. Siddiquei, M. I., \& Khan, W. (2020). Economic implications of coronavirus. Journal of Public Affairs, 20(4). https://doi.org/10.1002/pa.2169

50. Singh, B., Dhall, R., Narang, S., \& Rawat, S. (2020). The Outbreak of COVID-19 and Stock Market Responses: An Event Study and Panel Data Analysis for G-20 Countries. Global Business Review. https://doi.org/10.1177/0972150920957274

51. Joshi, A., Bhaskar, P., \& Gupta, P. K. (2020). Indian economy amid COVID-19 lockdown: A prespective. Journal of Pure and Applied Microbiology, 14, 957-961. https://doi.org/10.22207/JPAM.14.SPL1.33

52. Mazur, M., Dang, M., \& Vega, M. (2020). COVID-19 and the march 2020 stock market crash. Evidence from S\&amp;P1500. Finance Research Letters. https://doi.org/10.1016/j.frl.2020.101690

53. He, P., Sun, Y., Zhang, Y., and Li, T. (2020). COVID-19's Impact on Stock Prices Across Different Sectors-An Event Study Based on the Chinese Stock Market. Emerging Markets Finance and Trade, 56(10), $2198-2212$. https://doi.org/10.1080/1540496X.2020.1785865

54. Liu, M., Choo, W.-C., \& Lee, C.-C. (2020). The response of the stock market to the announcement of global pandemic. Emerging Markets Finance and Trade, 56(15), 3562-3577.

55. Chaudhary, R., Bakhshi, P., \& Gupta, H. (2020). The performance of the Indian stock market during COVID-19. Investment Management and Financial Innovations, 17(3), 133-147. https://doi.org/10.21511/imfi.17(3).2020.11

56. Lee, K. Y.-M., Jais, M., \& Chan, C.-W. (2020). Impact of covid-19: Evidence from malaysian stock market. International Journal of Business and Society, 21(2), 607-628.

57. Shehzad, K., Xiaoxing, L., Arif, M., Rehman, K. U., \& Ilyas, M. (2020). Investigating the Psychology of Financial Markets During COVID-19 Era: A Case Study of the US and European Markets. Frontiers in Psychology, 11. https://doi.org/10.3389/fpsyg.2020.01924

58. Lima, C. K. T., de Medeiros Carvalho, P. M., Lima, I. de A. S., de Oliveira Nunes, J. V. A., Saraiva, J. S., de Souza, R. I., ... Neto, M. L. R. (2020). The emotional impact of Coronavirus 2019-nCoV (new Coronavirus disease). Psychiatry Research, 112915.

59. Huo, X., \& Qiu, Z. (2020). How does China's stock market react to the announcement of the COVID-19 pandemic lockdown? Economic and Political Studies. https://doi.org/10.1080/20954816.2020.1780695

60. Hoshi, T., \& Kashyap, A. K. (2004). Japan's financial crisis and economic stagnation. Journal of Economic Perspectives, 18 (1), 3-26.

61. Goodell, J. W. (2020). COVID-19 and finance: Agendas for future research. Finance Research Letters, 35. https://doi.org/10.1016/j.frl.2020.101512

62. Phan, D. H. B., \& Narayan, P. K. (2020). Country Responses and the Reaction of the Stock Market to COVID-19-a Preliminary Exposition. Emerging Markets Finance and Trade, 56(10), 2138-2150. https://doi.org/10.1080/1540496X.2020.1784719

63. Narayan, P. K., Devpura, N., \& Wang, H. (2020). Japanese currency and stock market-What happened during the COVID-19 pandemic? Economic Analysis and Policy, 68, 191-198. https://doi.org/10.1016/j.eap.2020.09.014

64. Ashraf, B. N. (2020). Stock markets' reaction to COVID-19: Cases or fatalities? Research in International Business and Finance, 54. https://doi.org/10.1016/j.ribaf.2020.101249

65. Harjoto, M. A., Rossi, F., \& Paglia, J. K. (2020). COVID-19: stock market reactions to the shock and the stimulus. Applied Economics Letters. https://doi.org/10.1080/13504851.2020.1781767

66. Waheed, R., Sarwar, S., Sarwar, S., \& Khan, M. K. (2020). The impact of COVID-19 on Karachi stock exchange: Quantile-onquantile approach using secondary and predicted data. Journal of Public Affairs, 20(4). https://doi.org/10.1002/pa.2290

67. Wagner, A. F. (2020). What the stock market tells us about the post-COVID-19 world. Nature Human Behaviour, 4(5), 440. https://doi.org/10.1038/s41562-020-0869-y. 